Ambiente \& Água - An Interdisciplinary Journal of Applied Science
ISSN 1980-993X - doi:10.4136/1980-993X
www.ambi-agua.net
E-mail: ambi-agua@agro.unitau.br

\title{
Ecological water quality assessment in the Guapiaçu-Macacu hydrographic complex (Rio de Janeiro, Brazil) using multiple indicators
}

\author{
doi: 10.4136/ambi-agua.1397
}

Received: 14 May. 2014; Accepted: 02 Jul 2014

\author{
Priscilla S. Pereira' ${ }^{1}$; Lia A. C. Fernandes ${ }^{2}$, Roberto J. P. Dias ${ }^{3}$; \\ Marcelo S. Sampaio ${ }^{1}$; Inácio D. Silva-Neto ${ }^{4}$; Darcilio F. Baptista ${ }^{2}$; \\ Jaime L. M. Oliveira ${ }^{*}$ \\ ${ }^{1}$ Escola Nacional de Saúde Pública Sérgio Arouca (DSSA/ENSP/FIOCRUZ), Rio de Janeiro, RJ, Brasil \\ ${ }^{2}$ Instituto Oswaldo Cruz (LAPSA/IOC/FIOCRUZ), Rio de Janeiro, RJ, Brasil \\ ${ }^{3}$ Universidade Federal de Juiz de Fora (UFJF), Juiz de Fora, MG, Brasil \\ ${ }^{4}$ Centro de Ciências da Saúde (IB/CCS/UFRJ), Rio de Janeiro, RJ, Brasil \\ *Corresponding author: e-mail: jaimel@ensp.fiocruz.br, \\ pris.pereira@ioc.fiocruz.br, lia_acf@hotmail.com,rjuniodias@hotmail.com, \\ sampaio@ensp.fiocruz.br,idsnet@biologia.ufrj.br, darcilio@ioc.fiocruz.br
}

\begin{abstract}
A quick diagnosis of the ecological quality of five sections of the Macacu-Guapiaçu hydrographic complex was performed using visual assessment protocol (VAP), conventional analysis, composition and structure of ciliates and the occurrence of benthic macro invertebrates. Water samples were collected from five sampling stations (A-E) in July of 2010. Protists were sampled with aid of artificial substrates, and macro invertebrates were sampled using the multi-habitat method. A total of 22 taxa of protozoa and 51 taxa of macro invertebrates was registered at the five stations. Reference station (A) showed greater protist diversity and higher values of BMWP-CETEC and IBE-IOC indices relating to macro invertebrates. The impacted stations ( $\mathrm{B}$ and $\mathrm{E}$ ) presented lower diversity and higher abundance of protozoa, as well as the lowest values for the rates. The four methods used were convergent to diagnose reference station (A), the impacted stations (B and E) and those in intermediate conditions ( $\mathrm{C}$ and $\mathrm{D})$. Thus, the methods were complementary, as the conventional parameters and ciliate assembly were more sensitive to detecting the increase in organic pollution and VAP and macro invertebrate assembly detected changes in geomorphology and habitat degradation.
\end{abstract}

Keywords: bioindicators, lotic ecosystem, protozoans, macro invertebrates, visual assessment protocol.

\section{Avaliação da qualidade ecológica da água do complexo hidrográfico Guapiaçu-Macacu (Rio de Janeiro, Brasil) usando múltiplos indicadores}

\section{RESUMO}

O diagnóstico rápido da qualidade da água de cinco pontos do complexo hidrográfico Macacu-Guapiaçu foi realizado utilizando protocolo de avaliação visual (PAV), análises 
convencionais, composição e estrutura do grupo de ciliados e a ocorrência de macroinvertebrados bentônicos. Foram realizadas coletas de amostras da água em cinco pontos amostrais (A - E) em julho de 2010. Os protistas foram amostrados com auxílio de substratos artificiais e os macroinvertebrados utilizando método multi-habitat. Foram registrados 22 táxons de protozoários e 51 táxons de macroinvertebrados nas cinco amostras. $\mathrm{O}$ ponto de referência (A) apresentou maior diversidade de protistas e maiores índices BMWP-CETEC e IBE-IOC em relação aos grupos de macroinvertebrados. Os trechos mais impactados apresentaram menor diversidade e maior abundância de protozoários bem como menores valores para os índices. Os quatro métodos utilizados foram convergentes ao diagnosticar os trechos de referência (A), impactado (B e E) e com grau intermediário de impacto $(\mathrm{C}$ e $\mathrm{D})$. Além disso, estes métodos foram complementares visto que os parâmetros convencionais e a composição de ciliados foram mais sensíveis na detecção do aumento da poluição orgânica enquanto que o PAV e a ocorrência de macroinvertebrados detectaram alterações na geomorfologia e degradação do habitat.

Palavra-chave: bioindicadores, ecossistema lótico, protozoários, macroinvertebrados, protocolo de avaliação visual.

\section{INTRODUCTION}

No environment has undergone so many and such great changes throughout human history as aquatic ecosystems, notably surface water currents. Maintaining the quality of surface water has been a challenge, especially in developing countries like Brazil. This is because many rivers have been degraded for various reasons, such as the changing of their courses, the direct disposal of waste and disordered land use (Bergallo et al., 2009). Such impacts hinder the use of these water sources for public water supply and leisure activity (Von Sperling, 2007). The quality of Brazilian surface waters is evaluated according to Resolution $357 / 2005$ (Brasil, 2005) and in the case of intense fluvial mesh that exists in Brazil, effective monitoring is still incipient. Moreover, many of the parameters used by this resolution do not take into account the ecological quality of water. For such an assessment, is necessary to use additional and more sensitive parameters that reflect certain impacts such as rapid assessment protocol (Barbour et al., 1999) and use indicator organisms groups (Madoni and Braghiroli, 2007; Baptista, 2008).

Protists are an important component of the plankton and benthos of freshwater ecosystems (Madoni and Zangrossi, 2005). The ciliated protozoa are important consumers of bacteria and significantly influence the processes of decomposition in limnic ecosystems. Ciliates respond more quickly to environmental contamination than other groups of organisms due to their high reproductive rate, wide geographic distribution, easy laboratory cultivation and maintenance, high sensitivity to a changing environment, and variety of niche occupation (Madoni, 2005). In recent years, several studies have addressed the composition, distribution and dynamics of assemblies of ciliates in aquatic ecosystems (Primc-Habdija et al., 1998; Madoni, 2005), but few studies of lotic systems were performed in Brazil (Dias et al., 2008). There are different methods used in the study of ciliates in freshwater environments, and artificial substrates present advantages over other methods such as reduction of spatial heterogeneity and precision in data collection due to the standardization of the sample area and the start time of the colonization process (Coppellotti and Matarazzo, 2000).

Benthic macro invertebrates live in river beds, lakes, ponds and reservoirs and in at least one phase of their life cycle are considered good water quality indicators to monitor non-point sources of pollution. They have a wide geographic distribution, low migration, and long life cycle that allows time analysis (Bonada et al., 2006). Studies using macro invertebrates as indicators usually employ mono-metric biotic rates, i.e., those who attribute a score for each 
species based on tolerance to impact (Baptista, 2008). Biotic rates currently used in monitoring studies are BMWP (Biological Monitoring Working Party Score System) and IBI (Index of Biotic Integrity) (Karr, 1981).

This study performed a quick diagnosis of surface water ecological quality on five sections (A-E) of Macacu-Guapiaçu hydrographic complex in Rio de Janeiro, Brazil using four different methods: visual assessment protocol (VAP), physical, chemical and microbiological water analysis (conventional parameters), composition and structure of the protist with emphasis on ciliates and occurrence of the benthic macro invertebrates. In addition, these data were compared to obtain a standard for impact degree based on those methods.

\section{MATERIAL AND METHODS}

\subsection{Study area}

The study area comprises the eastern portion of Guanabara Bay in the central part of the Serra do Mar Ridge, corresponding to the Guapiaçu Macacu basin and rivers (MacacuGuapiaçu hydrographic complex), in the Atlantic Forest area in the state of Rio de Janeiro, Brazil. The land in this region is predominantly rural, with areas encompassing green biomass with remnant vegetation and extensive areas of agriculture and pasture. The MacacuGuapiaçu hydrographic complex has a drainage area of about $1,500 \mathrm{~km}^{2}$, with a population above 100,000 inhabitants. Its waters serve approximately 2.5 million inhabitants with irrigation, fish farming, agriculture and public supply (Helder, 1999).

Five sampling stations were selected, two in the Macacu River A $\left(22^{\circ} 25^{\prime} 14.8 " \mathrm{~S}\right.$, $\left.42^{\circ} 37^{\prime} 38.3^{\prime \prime} \mathrm{W}\right)$ and B $\left(22^{\circ} 28^{\prime} 53.4^{\prime \prime S}, 42^{\circ} 39^{\prime} 24.2^{\prime \prime W}\right)$, and three on the Guapiaçu River C $\left(22^{\circ} 26^{\prime} 28.5^{\prime \prime} \mathrm{S}, \quad 42^{\circ} 45^{\prime} 45^{\prime \prime} \mathrm{W}\right), \quad \mathrm{D}\left(22^{\circ} 31^{\prime} 29^{\prime \prime} \mathrm{S}, 42^{\circ} 49^{\prime} 53.3^{\prime \prime} \mathrm{W}\right)$, and E $\left(22^{\circ} 35^{\prime} 32.8^{\prime \prime} \mathrm{S}\right.$, $42^{\circ} 53^{\prime} 18^{\prime \prime W}$ ) (Figure 1). A, C and D stations are located in the region of the basin with the lowest human occupation as compared to $\mathrm{B}$ and $\mathrm{E}$ stations, which receive high load of domestic sewage.

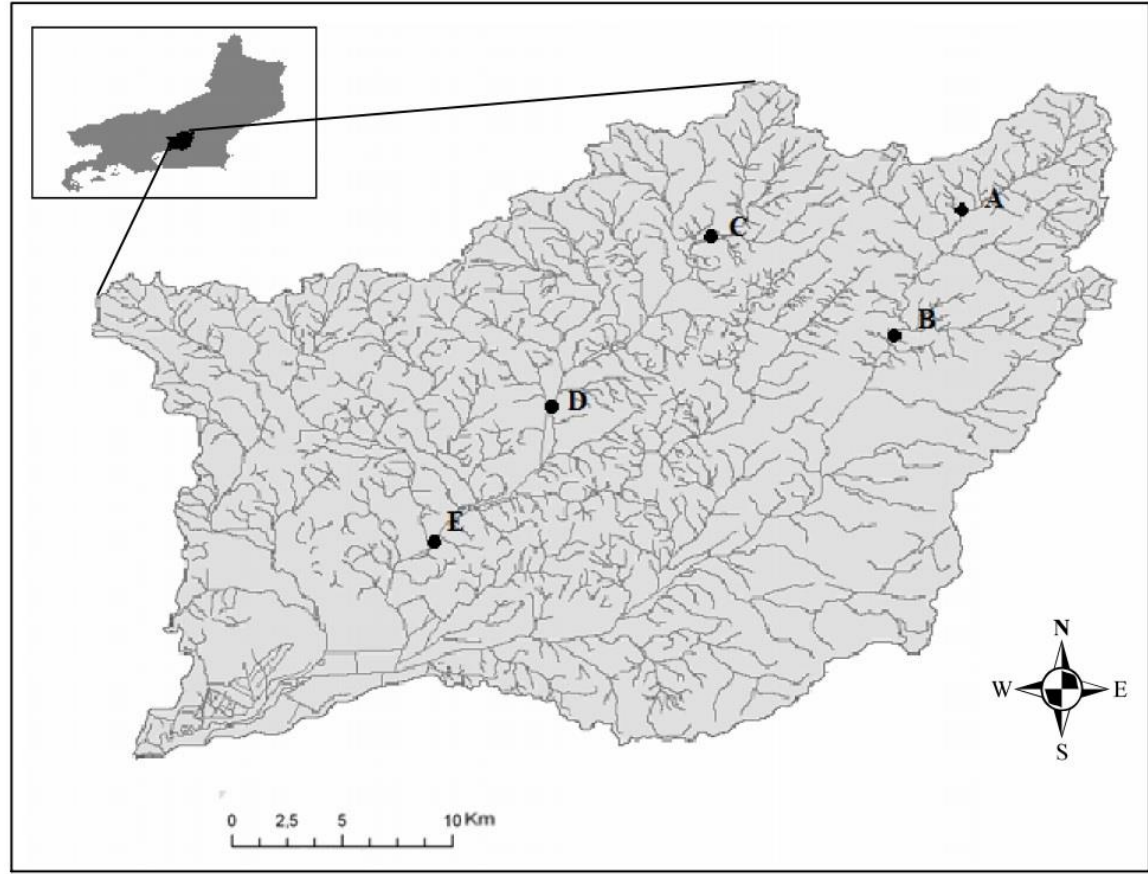

Figure 1. Map of the hydrographic complex Guapiaçu-Macacu, located in the eastern portion of the Guanabara Bay, Rio de Janeiro, with the location of the five sampling stations. Stations A and B are located in Macacu River and stations C, D and E in the Guapiaçu River. 


\subsection{Collections and sample processing}

Collections at the five sampling stations were performed in July 2010. One liter of water was collected in triplicate at the five sampling stations to conduct physical, chemical and microbiological analysis. The samples were stored at $4{ }^{\circ} \mathrm{C}$ and analyzed in the laboratory hours after being collected.

Traps with artificial substrates were used for the protozoa analysis. These traps were made of 12 cover slips ( $24 \times 24 \mathrm{~mm})$, arranged in an acrylic rectangular box $6 \mathrm{~cm}$ long and $3.5 \mathrm{~cm}$ wide, with openings on the sides, allowing the free flow of water through the cover slips. These substrates remained submerged in each of the five sampling stations for ten days, in order to provide sufficient time for protist colonization (Xu et al., 2009). After this period, each trap was placed inside a polypropylene box and transported with river water to the laboratory for identification and quantification of specimens.

The collection of benthic macro invertebrates was conducted by the Multi-Habitat method, which is based on proportional sampling of different microhabitats (substrates) available in each river reach (Barbour et al., 1999). A kick-net sampler with a $500 \mu \mathrm{m}$ mesh was used. In each section, an area of approximately 20 times the width of the river was sampled, with 20 separate withdrawals. All samples were merged (20 $\mathrm{m}^{2}$ of substrate), fixed and stored in $80 \%$ ethanol and subsequently transported to the laboratory.

\subsection{Physical, chemical and bacteriological parameters}

The $\mathrm{pH}$, conductivity, total dissolved solids (TDS), dissolved oxygen (DO) and temperature analyses were carried out using a multi-parameter probe, Model HI 9828 (HANNA). Turbidity was determined by a turbidity meter, Model 2100P (HACH). Biochemical oxygen demand (BOD), color, total nitrogen, $\mathrm{NH}_{3}-\mathrm{N}, \mathrm{NO}_{3}-\mathrm{N}$, total phosphorus, chloride, calcium, magnesium, fecal coliforms and total heterotrophic bacteria were evaluated according to Standard Methods (APHA et al., 2012).

\subsection{Visual Assessment Protocols (VAP)}

Sampling stations were classified as impacted, regular, or reference, based on visual assessment protocol (Barbour et al., 1999) and dissolved oxygen content in water. The visual assessment protocol reviews ten environmental parameters, such as sediment type, margin stability, riparian vegetation and natural substrates available for colonization by benthic fauna in the lotic system. Parameters are individually valued between 0 and 20, with values between 0 and 5, indicating an impacted location, from 5.1 to 9.9, indicating regular environmental conditions, from 10 to 14.9, indicating environment in good conditions and between 15 and 20 , indicating protected area.

\subsection{Protozoa and benthonic macro invertebrates}

For in vivo identification of protozoa, three cover slips of each artificial substrate were analyzed, a total of nine cover slips per sample station, using a microscope with differential interferential contrast in 100x, 200x and 1000x magnification. According to Foissner et al. (2002), in vivo observations of ciliates are essential for the correct identification of these microorganisms. The following characteristics were analyzed for the species of ciliates found: body shape, nuclear apparatus, contractile vacuole position and collector channels, cytoplasmic staining and cortical granules, mioneme organization (on the stalked species only), details of the dorsal surface (dorsal ribs and ciliature), disposition of cilia and somatic cirri, and oral ciliature arrangement. In vivo biometries were performed to confirm the specific identification of some of the ciliate species. Protists were identified according to a specialized bibliography (Foissner and Berger, 1996; Lynn, 2008). Quantification of protozoa was performed by choosing randomly among the remaining three cover slips out of nine acrylic traps, with nine cover slips quantified in each sampling station. All protozoa present 
on the surface of the cover slips were quantified.

Macro invertebrate specimens were collected and fixed in the field and were washed later at the laboratory to remove twigs, leaves, and sediments. Subsamples were then taken, according to Oliveira et al. (2011), ensuring that at least 150 individuals per subsample were identified. Macro invertebrates were observed by stereoscopic microscope and identified to genus level for most families found, using the macro invertebrate identification manual for Rio de Janeiro State, prepared by Mugnai et al. (2010).

\subsection{Data analysis}

The calculation of diversity rates, evenness and dominance for the protozoa assembly on the five sampling stations was performed using the Past 5.0 program (Hammer et al., 2001). The BMWP-CETEC (Junqueira et al., 1998) and IBE-IOC indices (Mugnai et al., 2008) were calculated for the benthic macro invertebrate assembly at the five sampling stations.

\section{RESULTS AND DEBATES}

\subsection{Environmental parameters}

The five sampling stations were previously analyzed applying the visual assessment protocol (VAP) to classify the type of landscape (Table 1). In the Macacu River, Station A was considered the study reference point, with the highest score (11.1), while Station B was classified as impacted. In the Guapiaçu River, Stations C and D were classified as having a regular condition, suggesting intermediate levels of impact (6.7 and 5.4 respectively), while Station E presented the lowest value (2.5), indicating an impacted environment.

VAP has an evaluation spectrum that seeks to maintain and protect riparian margins, as well as the formation of islets in the river bed and the reduction of its depth (Rodrigues et al., 2008). On the sampling stations considered reference (A) and regular (C and D), favorable substrates for aquatic biota colonization were found, indicating the presence of microhabitats that provide food and shelter for the maintenance of aquatic life. In Stations C and D, higher values for margin stability were recorded, indicating conserved riparian zones, stations less susceptible to suffer impact caused by runoff in lotic systems (Curvello et al., 2008, Coelho et al., 2011). Stations B and $E$ have reduced riparian vegetation and major silting of the bed, suggesting they shelter less biological diversity (Lucas and Cunha, 2007).

Values of the physical, chemical and bacteriological parameters obtained from the five sampling stations are shown in Table 1. Many of the obtained values are within the limits recommended by Resolution 357/2005 (Brasil, 2005), except for biochemical oxygen demand (BOD), oxygen, color and thermotolerant coliforms in some stations. Although no significant difference between values of the physical, chemical and bacteriological water parameters among the five sampling stations has been observed, the detection of measurable levels of ammonia, calcium and magnesium in Stations B and E only suggest heterogeneity among sampling stations. Samples from B and E stations were classified as impacted by visual assessment protocol, and presented higher electrical conductivity, turbidity, color, total density of heterotrophic bacteria, and were the only fifth-order stations in this study (Table 1). Only these stations (B and E) had water samples with measurable levels of ammonia, calcium and magnesium, which corroborates the results obtained in the visual assessment protocol, suggesting greater environmental degradation in those stations. Sampling station A, classified as reference by the VAP, showed the highest values of dissolved oxygen and lowest values of electrical conductivity, total dissolved solids, turbidity, color and total density of heterotrophic bacteria (Table 1). In this study, the values obtained by the VAP greatly contributed to reach a clear differentiation of stations according to their environmental impact, as highlighted in the study by Pereira et al. (2012). 
Table 1. Physical, chemical and bacteriological parameters of the five sampling stations in the GuapiaçuMacacu hydrographic complex, Rio de Janeiro, Brazil.

\begin{tabular}{|c|c|c|c|c|c|}
\hline $\begin{array}{c}\text { Physical, chemical and microbiological } \\
\text { parameters }\end{array}$ & $\mathbf{A}$ & B & $\mathbf{C}$ & $\mathbf{D}$ & $\mathbf{E}$ \\
\hline Dissolved Oxygen $\left(\mathrm{mg} \mathrm{L}^{-1}\right)$ & $9.6 \pm 0.1$ & $9.4 \pm 0.1$ & $6.1 \pm 0.2$ & $6.2 \pm 0.3$ & $5.4 \pm 0.4$ \\
\hline Visual Assessment Protocol (VAP) & 11.1 & 4.1 & 6.7 & 5.4 & 2.5 \\
\hline $\mathrm{pH}$ & $7.5 \pm 0.2$ & $7.5 \pm 0.2$ & $7.6 \pm 0.2$ & $7.9 \pm 0.1$ & $6.9 \pm 0.1$ \\
\hline Temperature $\left({ }^{\circ} \mathrm{C}\right)$ & $18.2 \pm 0.1$ & $23.7 \pm 0.1$ & $20.6 \pm 0.1$ & $19.3 \pm 0.3$ & $22.9 \pm 0.1$ \\
\hline Conductivity $\left(\mu \mathrm{S} \mathrm{cm}^{-1}\right)$ & $16 \pm 2$ & $33 \pm 1$ & $21 \pm 1$ & $25 \pm 2$ & $37 \pm 8$ \\
\hline Total Dissolved Solids (mg L ${ }^{-1}$ ) & $8 \pm 1$ & $17 \pm 1$ & $10 \pm 1$ & $13 \pm 1$ & $18 \pm 4$ \\
\hline Turbidity (NTU) & $1 \pm 1$ & $5 \pm 1$ & $3 \pm 1$ & $5 \pm 1$ & $7 \pm 1$ \\
\hline Color $\left(\mathrm{Hu}^{*}\right)$ & $20 \pm 2$ & $46 \pm 5$ & $43 \pm 2$ & $52 \pm 5$ & $78 \pm 6$ \\
\hline Biochemical Oxygen Demand $\left(\mathrm{mg} \mathrm{L}^{-1}\right)$ & $11.8 \pm 1.7$ & $21.6 \pm 0.3$ & $9.3 \pm 0.1$ & $9.5 \pm 0.9$ & $9.8 \pm 1.5$ \\
\hline $\mathrm{N}-\mathrm{NH}_{3}\left(\mathrm{mg} \mathrm{L}^{-1}\right)$ & - & $0.083 \pm 0.06$ & - & - & $0.042 \pm 0.024$ \\
\hline $\mathrm{N}-\mathrm{NO}_{3}\left(\mathrm{mg} \mathrm{L}^{-1}\right)$ & $0.04 \pm 0.01$ & $0.5 \pm 0.01$ & $0.01 \pm 0.01$ & $0.05 \pm 0.01$ & $0.04 \pm 0.01$ \\
\hline Total Nitrogen $\left(\mathrm{mg} \mathrm{L}^{-1}\right)$ & $0.77 \pm 0.07$ & $1.36 \pm 0.21$ & $0.61 \pm 0.38$ & $0.74 \pm 0.37$ & $0.57 \pm 0.12$ \\
\hline Total Phosphorus (mg L ${ }^{-1}$ ) & $0.3 \pm 0.21$ & $0.47 \pm 0.30$ & $0.28 \pm 0.06$ & $0.29 \pm 0.11$ & $0.27 \pm 0.02$ \\
\hline Calcium (mg L $\left.{ }^{-1}\right)$ & - & $3.3 \pm 0.1$ & - & - & $3.0 \pm 1.1$ \\
\hline Magnesium $\left(\mathrm{mg} \mathrm{L}^{-1}\right)$ & - & $0.4 \pm 0.1$ & - & - & $0.9 \pm 0.5$ \\
\hline Chlorides $\left(\mathrm{mg} \mathrm{L}^{-1}\right)$ & $0.07 \pm 0.01$ & $0.13 \pm 0.01$ & $0.07 \pm 0.01$ & $0.13 \pm 0.04$ & $0.13 \pm 0.01$ \\
\hline Stream order & 4 & 5 & 4 & 4 & 5 \\
\hline Mean width (m) & 15 & 25 & 15 & 15 & 32 \\
\hline Thermotolerant Coliforms (NMP $100 \mathrm{~mL}^{-1}$ ) & $396 \pm 307$ & $1483 \pm 99$ & $438 \pm 297$ & $78 \pm 5$ & $434 \pm 304$ \\
\hline Total Heterotrophic Bacteria $\left(\mathrm{UFC} \mathrm{mL}^{-1}\right)$ & $55 \pm 25$ & $312 \pm 98$ & $156 \pm 53$ & $80 \pm 34$ & $276 \pm 8$ \\
\hline
\end{tabular}

Note: $\left(^{*}\right)$ Hazen unit

\subsection{Ciliated protozoa}

All five stations presented protist specimens. In all, 19 species of ciliated protozoa were recorded, as well as testate amoebas (Table 2). Among the protozoa registered, some taxa were found exclusively in a single sampling station, such as Amphileptus sp. and Chilodonella sp. at A; Spirotomum minus, Loxophyllum sp. and Rhabdostyla sp. at station 2; Centropyxis spp. at C; Dileptus sp., Tetmemena pustulata and Cinetochilum margaritaceum in D and Peranema spp., Arcella spp., Platycola decumbens, Epistylis plicatilis , Lembadion lucens and Stentor sp. at E. Some species occurred in sampling stations with different degrees of environmental degradation, such as Frontonia leucas. This ciliate has broad ecological valence and is omnivorous, and was previously recorded along the pollution gradient in a lotic system (Dias et al., 2008).

The species Loxodes striatus and Vorticella convallaria-complex were recorded only in the sampling stations (B and E) classified as impacted by the VAP. Loxodes striatus is a species typical of the anoxic benthic ciliate community (Fenchel and Finlay, 1984; Patterson, 
1996), corroborating the results obtained by the VAP, as well as the physical, chemical and bacteriological water parameters of those sampling stations. The Vorticella convallariacomplex species has been recorded in other organically enriched stream ecosystems, and was recorded in high abundance and frequency in sampling stations of Italy River with high electrical conductivity and high concentration of nutrients (Madoni and Bassanini, 1999).

Among the 19 species of ciliates found, five are peritrich ciliates (Subclass Peritrichia): Carchesium polypinum, Epistylis plicatilis, Platycola decumbens, Rhabdostyla sp. and Vorticella convallaria-complex (Table 2). These microeukaryotes are considered good indicators of organic pollution (Kusuoka \& Watanabe, 1987; Stöessel, 1987). The high abundance of Rhabdostyla sp. recorded at sampling Station B and Carchesium polypinum, Epistylis plicatilis and Vorticella convallaria-complex in sampling Station E suggest a greater degree of degradation in those two sampling stations. According to Kusuoka \& Watanabe (1987), urban streams receiving sewage can be considered the ideal habitat for ciliates. Taylor (1983) reports that peritrichs have high growth rates in eutrophic lotic systems. According to Stöessel (1987), peritrichs, besides taking advantage of organic pollution in urban rivers and streams, since they are mostly bacterivorous organisms, are also less susceptible than other groups of ciliates to the wide variation of flow in these systems due to their mode of sessile life.

A higher abundance of ciliates was observed at Stations B and E (101 and 240, respectively), with relative contribution of peritrich ciliates species. The increased organic enrichment observed in those sampling stations favors growth of the total heterotrophic bacteria density that sustains bacterivorous ciliates populations (Madoni, 2005). According to a study by Madoni and Bassanini (1999), organic pollution not only changes the structure and composition of the ciliate assembly, but also modifies its abundance, and degraded environments present higher total abundance of ciliates, as was also recorded in this study. The highest dominance values and the lowest diversity and evenness values of the ciliate assembly were observed at Stations B and E, emphasizing the greater environmental impact those stations present. According to data obtained by Madoni and Bassanini (1999), although sampling stations with high levels of organic pollution have similar species richness of ciliates, their diversity in those stations suffers significant decrease.

\subsection{Macro invertebrates}

A total of 5,213 individuals belonging to 51 taxa were found in the samples obtained. Species of the phyla Arthopoda, Anellida and Mollusca were recorded. Within the species of Arthropoda, one was a decapod crustacean (Palaemon pandaliformis) and eight insect orders representing 36 families (Table 3) were also found. Among those families, five occurred in the five sampling stations: Leptophyphidae (Thricorythopsis), Hydropsychidae (Smicridea), Elmidae (Heterelmis), Chironomidae and Simullidae. Among the insects, the most abundant order was Diptera (63\%), followed by Ephemeroptera (25\%). Order Trichoptera showed greatest richness of families (8 families). The Elmidae family (Coleoptera), a taxon considered tolerant (Piedras et al., 2006), showed higher abundance in the less impacted sampling stations $\mathrm{A}, \mathrm{C}$ and $\mathrm{D}$, suggesting that despite their resistance to impacted areas, they prefer less impacted areas.

Some insect families were recorded only in the minimally impacted areas of Macacu (A) and Guapiaçu (C) Rivers, such as Grypopterygidae (Plecoptera), Vellidae (Hemiptera) and Philopotamidae (Trichoptera). Those families are commonly recorded in less impacted lotic systems in the neotropical region (Oliveira, 2013). The taxa most sensitive to pollution, Helicopsychidae and Calamoceratidae (Trichoptera) and Dixidae (Diptera) (Gabriels et al. 2010; Hepp et al., 2013), were only registered at the sampling station classified by the VAP as a reference station $(\mathrm{A})$. 
Table 2. Composition, abundance and ecological indices of the protozoa assembly (emphasis on ciliates) found in the five sampling stations of the Guapiaçu-Macacu hydrographic complex, Rio de Janeiro, Brazil.

\begin{tabular}{|c|c|c|c|c|c|}
\hline \multirow{2}{*}{ Protozoa Species } & \multicolumn{5}{|c|}{ Stations } \\
\hline & $\mathbf{A}$ & $\mathbf{B}$ & $\mathbf{C}$ & D & $\mathbf{E}$ \\
\hline \multicolumn{6}{|l|}{ Ciliates (Alveolata: Ciliophora } \\
\hline Aspidisca cicada & + & 0 & + & 0 & 0 \\
\hline Amphileptus sp. & + & 0 & 0 & 0 & 0 \\
\hline Carchesium polypinum & + & 0 & 0 & + & + \\
\hline Chilodonella sp. & + & 0 & 0 & 0 & 0 \\
\hline Cinetochilum margaritaceum & 0 & 0 & 0 & + & 0 \\
\hline Dileptus sp. & 0 & 0 & 0 & + & 0 \\
\hline Epistylis plicatilis & 0 & 0 & 0 & 0 & + \\
\hline Frontonia leucas & + & 0 & + & 0 & + \\
\hline Lembadion lucens & 0 & 0 & 0 & 0 & + \\
\hline Litonotus sp. & 0 & 0 & + & + & + \\
\hline Loxodes striatus & 0 & + & 0 & 0 & + \\
\hline Loxophyllum sp. & 0 & + & 0 & 0 & 0 \\
\hline Paramecium aurelia & 0 & 0 & + & + & 0 \\
\hline Platycola decumbens & 0 & 0 & 0 & 0 & + \\
\hline Rhabdostyla sp. & 0 & + & 0 & 0 & 0 \\
\hline Spirostomum minus & 0 & + & 0 & 0 & 0 \\
\hline Stentor sp. & 0 & 0 & 0 & 0 & + \\
\hline Tetmemena pustulata & 0 & 0 & 0 & + & 0 \\
\hline Vorticella convallaria-complex & 0 & + & 0 & 0 & + \\
\hline
\end{tabular}

Other protists (tecamoebas and flagellates)

\begin{tabular}{lccccc}
\hline Arcella spp. & 0 & 0 & 0 & 0 & + \\
Centropyxis spp. & 0 & 0 & + & 0 & 0 \\
Peranema spp. & 0 & 0 & 0 & 0 & + \\
\hline Ecological Index & $\mathbf{A}$ & $\mathbf{B}$ & $\mathbf{C}$ & $\mathbf{D}$ & $\mathbf{E}$ \\
\hline Abundance & 29 & 101 & 25 & 27 & 240 \\
Dominance & 0.241 & 0.453 & 0.347 & 0.229 & 0.667 \\
Shannon-Wiener index & 1.507 & 0.939 & 1.323 & 1.592 & 0.782 \\
Equitability & 0.937 & 0.677 & 0.739 & 0.889 & 0.326 \\
\hline
\end{tabular}

Note: (+) presence; (0) absent. 
Table 3. Composition and abundance of the macro invertebrate assembly found in the five sampling stations of Guapiaçu-Macacu hydrographic complex, Rio de Janeiro, Brazil, and values of biotic indices BMWP and IBE found in each station.

\begin{tabular}{|c|c|c|c|c|c|}
\hline \multirow{2}{*}{ Macro Invertebrate } & \multicolumn{5}{|c|}{ Stations } \\
\hline & $\mathbf{A}$ & $\mathbf{B}$ & $\mathbf{C}$ & D & $\mathbf{E}$ \\
\hline Baetidae & 27 & 234 & 431 & 154 & 214 \\
\hline Leptohyphidae & 27 & 32 & 87 & 50 & 24 \\
\hline Calopterygidae & 0 & 4 & 6 & 3 & 5 \\
\hline Gomphidae & 1 & 2 & 4 & 3 & 5 \\
\hline Libellulidae & 0 & 3 & 1 & 10 & 1 \\
\hline Protoneuridae & 0 & 0 & 0 & 0 & 6 \\
\hline Grypopterygidae & 4 & 0 & 2 & 0 & 0 \\
\hline Perlidae & 11 & 0 & 2 & 3 & 11 \\
\hline Corixidae & 0 & 0 & 0 & 0 & 6 \\
\hline Naucoridae & 3 & 1 & 19 & 8 & 0 \\
\hline Vellidae & 1 & 0 & 4 & 0 & 0 \\
\hline Calamoceratidae & 10 & 0 & 0 & 0 & 0 \\
\hline Helicopsychidae & 19 & 0 & 0 & 0 & 0 \\
\hline Hydropsychidae & 23 & 31 & 30 & 13 & 13 \\
\hline Hydroptilidae & 0 & 2 & 0 & 0 & 0 \\
\hline Leptoceridae & 23 & 0 & 0 & 5 & 1 \\
\hline Odontoceridae & 3 & 1 & 17 & 5 & 0 \\
\hline Philopotamidae & 1 & 0 & 9 & 0 & 0 \\
\hline Sericostomatidae & 0 & 2 & 0 & 1 & 0 \\
\hline Pyralidae & 0 & 0 & 0 & 5 & 0 \\
\hline Elmidae & 100 & 3 & 32 & 58 & 13 \\
\hline Gyrinidae & 0 & 0 & 3 & 0 & 0 \\
\hline Hydrophilidae & 0 & 2 & 2 & 6 & 0 \\
\hline Lutrochidae & 0 & 0 & 0 & 0 & 2 \\
\hline Noteridae & 0 & 0 & 0 & 0 & 2 \\
\hline Psephenidae & 2 & 0 & 7 & 1 & 0 \\
\hline Ceratopogonidae & 1 & 2 & 0 & 1 & 0 \\
\hline Chironomidae & 512 & 1763 & 390 & 374 & 118 \\
\hline Dixidae & 30 & 0 & 0 & 0 & 0 \\
\hline Empididae & 5 & 20 & 2 & 9 & 0 \\
\hline Simulidae & 22 & 4 & 20 & 1 & 2 \\
\hline Tipulidae & 1 & 0 & 7 & 3 & 0 \\
\hline Palaemoninae & 0 & 0 & 0 & 1 & 20 \\
\hline Oligochaeta* & 0 & 4 & 1 & 0 & 0 \\
\hline Hydrobiidae & 1 & 0 & 0 & 0 & 0 \\
\hline Physidae & 0 & 43 & 0 & 0 & 0 \\
\hline \multicolumn{6}{|l|}{ Biotic Index } \\
\hline BMWP-CETEC & 131 & 81 & 127 & 115 & 73 \\
\hline IBE-IOC & 8 & 6 & 8 & 7 & 5 \\
\hline
\end{tabular}

Note: * Class of Phylum Annelida. 
Sampling stations characterized as impacted by the VAP presented occurrence of taxa tolerant to pollution, such as Hemiptera, Coleoptera, Diptera, physid molluscs and oligochaetes. The families Corixidae (Hemiptera), and Lutrochidae and Noteridae (Coleoptera) were collected exclusively at Station E (Guapiaçu River), and Physidae molluscs were found only in Station B (Macacu River). Tolerant dipteran families Chironomidae and Empididae and oligochaetes (Annelida) presented higher abundance at Station B. Studies of the structure of macro invertebrate assembly in neotropical lotic ecosystems frequently record those tolerant taxa in sites with a certain degree of environmental impact (Gabriels et al., 2010). The presence and high abundance of tolerant taxa, low taxa richness and greater total abundance of invertebrates $(2,179)$ at Station B, suggests a higher degree of degradation in that region, as demonstrated by physical, chemical and bacteriological data of water and VAP.

According to the results of biotic rates (BMWP-CETEC and IBE-IOC), Stations A and C present better environmental integrity, Stations B and E are the most impacted and Station D presents intermediate condition. The BMWP index is one of the metrics most used in biomonitoring studies in neotropical regions (Baptista et al., 2007; Bagatini et al., 2012). Suriano et al. (2011) developed a new multimetric index for southeastern Brazilian ecosystems, using as a basis the BMWP-CETEC index, and demonstrated the broad sensitivity of this metric investigating large regional scale. The IBE-IOC index, developed by Mugnai et al. (2008) for Rio de Janeiro (Brazil) freshwater ecosystems, allows distinction of different types of environmental impacts (deforestation and organic pollution) based on the structure of benthic macro invertebrate assembly. Although there are several research groups in Brazil investigating this assembly in shallow inland waters, there are proportionately few publications focusing on biological monitoring (Oliveira et al., 2011; Couceiro et al., 2012).

Taxa of benthic macro invertebrates found in this study were previously recorded in other lotic environments in the State of Rio de Janeiro (Silveira et al., 2006, Mugnai et al., 2010). Understanding the geographical distribution and ecological valence of these organisms will form the basis for future construction of biological rates for environmental management by watershed committees (Baptista et al., 2013).

\subsection{Integrated approach to water ecological quality}

Based on the application of the visual assessment protocol (VAP), conventional physical, chemical and microbiological parameters of water, structure and composition of the assembly of ciliated protozoa, and the use of biotic rates applied to the assembly of benthic macro invertebrates, it was possible to make a quick diagnosis of surface water ecological quality in five sections of Macacu-Guapiaçu hydrographic complex (Rio de Janeiro, Brazil).

Station A, classified as reference or good environment condition by the VAP, showed the highest values of dissolved oxygen and lower values of electrical conductivity, total dissolved solids, turbidity, color and total density of heterotrophic bacteria, as well as high protist diversity and higher values of BMWP and IBE indexes, highlighting the congruence between the methods used on this proposal. Stations C and D were found to be of intermediate ecological quality using the four methodological approaches adopted. Stations B and E were classified as impacted by the PAV, and presented detectable amounts of ammonia, calcium and magnesium as well as higher values of electrical conductivity, turbidity, color, and total density of heterotrophic bacteria. These stations also showed the lowest diversity and higher abundance of protozoa, as well as the lowest values of BMWP and IBE indices, emphasizing again the congruence between the four methods used to diagnose the ecological water quality of Macacu-Guapiaçu hydrographic complex.

Although data obtained in this study suggest the congruence between the methods used and their complementarity, highlighting the potential use of this approach in tropical lotic systems, further studies with a temporal approach to statistical confirmation of this 
congruence are required. This is the first study to use ciliate and macro invertebrate integratively in a quick assessment of water quality in neotropical stream ecosystems.

\section{CONCLUSIONS}

The four methods used to investigate the ecological water quality on five sections of Macacu-Guapiaçu hydrographic complex were convergent to diagnose the reference stations, and those impacted and intermediate conditions. They were also complementary, as water parameters and ciliate assembly were more sensitive in detecting the increase in organic pollution, and VAP and macro invertebrate assembly in detecting changes in geomorphology and habitat degradation.

\section{ACKNOWLEDGMENTS}

The authors would like to thank LAPSA/IOC/FIOCRUZ and DSSA/ENSP/FIOCRUZ, as well as the support from Valdiney Valin and Denise Borges. This project was financed by the CNPq/PROEP 400107/2001-2, FINEP and FAPERJ.

\section{REFERENCES}

AMERICAN PUBLIC HEALTH ASSOCIATION - APHA; AMERICAN WATER WORKS ASSOCIATION - AWWA; WATER ENVIRONMENT FEDERATION - WEF. Standard methods for the examination of water and wastewater. $22^{\text {th }}$ ed. Washington, DC, 2012.

BAGATINI, Y. M.; DELARIVA, R. L.; HIGUTI, J. Benthic macro invertebrate community structure in a stream of the north-west region of Paraná State, Brazil. Biota Neotropica, v. 12, n. 1, p. 307-317, 2012. http://dx.doi.org/10.1590/A676-06032012000100023

BAPTISTA, D. F.; BUSS, D. F.; EGLER, M.; GIOVANELLI, A.; SILVEIRA, M. P.; NESSIMIAN, J. A multimetric index based on benthic macro invertebrates for evaluation of Atlantic Forest streams at Rio de Janeiro State, Brazil. Hydrobiologia, v. 575, p. 83-94, 2007. http://dx.doi.org/10.1007/A0750-006-0286-x

BAPTISTA, D. F.; HENRIQUES-OLIVEIRA, A. L.; OLIVEIRA, R. B. S.; MUGNAI, R.; NESSIMIAN, J. L.; BUSS, D. F. Development of a benthic multimetric index for the serra da Bocaina bioregion in southeast Brazil. Brazilian Journal of Biology, v. 73, n. 3, p. 573-583, 2013. ttp://dx.doi.org/10.1590/A519-69842013000300015

BAPTISTA, D. F. Uso de macroinvertebrados em procedimentos de biomonitoramento em ecossistemas aquáticos. Oecologia Brasiliensis, v. 12, n. 3, p. 425-441, 2008.

BARBOUR, M. T.; GERRITSEN, J.; SNYDER, B. D.; STRIBLING, J. B. Rapid bioassessment protocols for use in streams and wadeable rivers: periphyton, benthic macro invertebrates and fish. $2^{\text {nd }}$ ed. Washington: USEPA, 1999.

BERGAllo, H. G.; FIDAlGO, E. C. C.; ROCHA, C. F. D.; UZÊDA, M. C.; COSTA, M. B.; ALVES, M. A. S. et al. Estratégias e ações para a conservação da biodiversidade no estado do Rio de Janeiro. Rio de Janeiro: Instituto Biomas, 2009. p. 344. 
BRASIL. Ministério do Meio Ambiente. Conselho Nacional do Meio Ambiente - CONAMA. Resolução $N^{\circ}$ 357, de 17 de Março de 2005. Dispõe sobre a classificação dos corpos de água e diretrizes ambientais para o seu enquadramento, bem como estabelece as condições e padrões de lançamento de efluentes, e dá outras providências. Diário Oficial [da] União, Brasília, DF, Poder Executivo, de 18 de Março de 2005.

BONADA, N.; PRAT, N.; RESH, V. H.; STATZNER, B. Developments in aquatic insect biomonitoring: a comparative analysis of recent approaches. Annual Review of $\begin{array}{llllllll}\text { Entomology, } & \text { v. } & 51, & \text { p. } & 495 & - & 523,\end{array}$ http://dx.doi.org/10.1146/annurev.ento.51.110104.151124

COELHO, R. C. T. P.; BUFFON, I.; GUERRA, T. Influência do uso e ocupação do solo na qualidade da água: um método para avaliar a importância da zona ripária. Revista Ambiente \& Água, v. 6, n. 1, p. 104-117, 2011. http://dx.doi.org/10.4136/ambiagua. 169

COPPELLOTTI, O.; MATARAZZO, P. Ciliate colonization of artificial substrates in the Lagoon of Venice. Journal of the Marine Biological Association of the United Kingdom, v. 80, p. $419-427,2000$.

COUCEIRO, S. R. M.; HAMADA, N.; FORSBERG, B. R.; PIMENTEL, T. P.; LUZ, S. L. B. A macro invertebrate multimetric index to evaluate the biological condition of streams in the Central Amazon region of Brazil. Ecological Indicators, v. 18, p. 118-125, 2012. http://dx.doi.org/10.1016/j.ecolind.2011.11.001

CURVELlo, R. T.; BATISTA, G. T.; TARGA, M. S. Estudo dos impactos da ocupação humana na microbacia do rio Bateador na Serra da Mantiqueira no município de Cruzeiro, SP, Brasil. Revista Ambiente \& Água, v. 3, n. 1, p. 91-107, 2008. http://dx.doi.org/10.4136/ambi-agua.45

DIAS, R. J. P.; WIELOCH, A. H.; D'AGOSTO, M. The influence of environmental characteristics on the distribution of ciliates (Protozoa, Ciliophora) in an urban stream of southeast Brazilian. Journal Biology, v. 68, n. 2, p. 287 - 295, 2008. http://dx.doi.org/10.1590/A519-69842008000200009

FENCHEL, T.; FINLAY, B. J. Geotaxis in the ciliated protozoon Loxodes. Journal of Experimental Biology, v. 110, p. 17 - 33, 1984.

FOISSNER, W.; AGATHA, S.; BERGER, H. Soil ciliates (Protozoa, Ciliophora) from Namibia (Southwest Africa), with emphasis on two contrasting environments, the Etosha region and the Namib Desert. Linz: Biologiezentrum des Oberösterr, 2002. $1459 \mathrm{p}$.

FOISSNER, W.; BERGER, H. A user-friendly guide to the ciliates (Protozoa, Ciliophora) commonly used by hydrobiologists as bioindicators in rivers, lakes, and waste waters, with notes on their ecology. Freshwater Biology, v. 35, p. 375 - 482, 1996. http://dx.doi.org/ 10.1111/j.1365-2427.1996.tb01775.x

GABRIELS, W.; LOCK, K.; PAUW, N.; GOETHALS, P. L. M. Multimetric Macro invertebrate Index Flanders (MMIF) for biological assessment of rivers and lakes in Flanders (Belgium). Limnologica - Ecology and Management of Inland Waters, v. 40, n. 3, p. 199-207, 2010. http://dx.doi.org/10.1016/j.limno.2009.10.001 
HAMMER, O.; HARPER, D. A. T.; RYAN, P. D. Past: Paleontological statistics software package for education and data analysis. Palaeontologia Electronica, v. 4, n. 1, p. 9, 2001.

HELDER, C. Subsídios para gestão dos recursos hídricos das bacias hidrográficas dos rios Macacu, São João, Macaé e Macabu. Rio de Janeiro: Secretaria do Meio Ambiente, 1999.

HEPP, L. U.; RESTELLO, R. M.; MILESI, S. V.; BIASI, C.; MOLOZZI, J. Distribution of aquatic insects in urban headwater streams. Acta Limnologica Brasiliensia, v. 25, n. 1, p. 1-09, 2013. http://dx.doi.org/10.1590/B179-975X2013005000014

JUNQUEIRA, V. M.; CAMPOS, S. C. M. Adaptation of the "BMWP" method for water quality evaluation to rio das Velhas watershed (Minas Gerais Brazil). Acta Limnológica Brasiliensia, v. 10, n. 2, p. 125-135, 1998.

KARR, J. R. Assessment of biotic integrity using fish communities. Fisheries, v. 6, p. 21-27, 1981. http://dx.doi.org/10.1577/1548-8446(1981)006<0021:AOBIUF>2.0.CO;2

KUSUOKA, Y.; WATANABE, Y. Growth and survival of peritrich ciliates in an urban stream. Oecologia, v. 73, n. 1, p. 16-20, 1987. http://dx.doi.org/10.1007/BF00376971

LYNN, D. The ciliated protozoa characterization, classification, and guide to the literature. $3^{\text {rd }}$ ed. New York: Springer, 2008. 606 p.

LUCAS, L. M.; CUNHA, S. B. Rede de drenagem urbana em área tropical: mudanças na morfologia do canal e níveis de poluição das águas - Rio dos Macacos, Rio de Janeiro. GEOUSP - Espaço e Tempo, n. 22, p. 39-64, 2007.

MADONI, P.: BASSANINI, N. Longitudinal changes in the ciliated protozoa communities along a fluvial system polluted by organic matter. European Journal of Protistology, n. 35. p. 391 - 402, 1999. http://dx.doi.org/10.1016/S0932-4739(99)80048-0

MADONI, P.; BRAGHIROLI, S. Changes in the ciliate assemblage along a fluvial system related to physical, chemical and geomorphological characteristics. European Journal of Protistology, v. 43, n. 2, p. 67-75, 2007. http://dx.doi.org/10.1016/j.ejop.2006.09.004

MADONI, P.; ZANGROSSI, S. Ciliated protozoa and saprobical evaluation of water quality in the Taro River (northern Italy). Italian Journal of Zoology, v. 72, n. 1, p. 21-25, 2005. http://dx.doi.org/10.1080/11250000509356648

MADONI, P. Ciliated protozoan communities and saprobic evaluation of water quality in the hilly zone of some tributaries of the Po River (northern Italy). Hydrobiologia, v. 541, n. 1, p. 55-69, 2005. http://dx.doi.org/10.1007/A0750-004-4667-8

MUGNAI, R.; BAPTISTA, D. F.; NESSIMIAN, J. L. Manual de identificação de macroinvertebrados aquáticos do Rio de Janeiro. Rio de Janeiro: Technical Books, 2010. 174 p.

MUGNAI, R.; OLIVEIRA, R. B.; LAGO CARVALHO, A.; BAPTISTA, D. F. Adaptation of the Índice Biotico Esteso (IBE) for water quality assessment in rivers of Serra do Mar, Rio de Janeiro state, Brasil. Tropical Zoology, v. 21, p. 57-74, 2008. 
OLIVEIRA, R. B. S.; MUGNAI, R.; CASTRO, C. M.; BAPTISTA, D. F. Determining subsampling effort for the development of a rapid bioassessment protocol using benthic macro invertebrates in streams of Southeastern Brazil. Environmental Monitoring and Assessment, v. 175, n. 1-4, p. 75-85, 2011. http://dx.doi.org/10.1007/A0661-010-14944

OLIVEIRA, R. B. S. Desenvolvimento de um índice multimétrico preditivo baseado na comunidade de macroinvertebrados bentônicos para avaliar a integridade ecológica de riachos no estado do rio de janeiro. 2013. Tese (Doutorado) Universidade Federal do Rio de Janeiro, 2013.

PATTERSON, D. J. Free-living freshwater protozoa: a color guide. New York: John Wiley \& Sons, 1996. 223p.

PEREIRA, P. S.; FERNANDES, L. A. C.; OLIVEIRA, J. L. M.; BAPTISTA, D. F. Avaliação da integridade ecológica de rios em áreas do zoneamento ecológico econômico do complexo hidrográfico Guapiaçu-Macacu, RJ, Brasil. Revista Ambiente \& Água, v. 7, n. 1, 2012. http://dx.doi.org/10.4136/ambi-agua.762

PIEDRAS, S. R. N.; BAGER, A.; MORAES, P. R. R.; ISOLDI, L. A.; FERREIRA, O. G. L.; HEEMANN, C. Macroinvertebrados bentônicos como indicadores de qualidade de água na Barragem Santa Bárbara, pelotas, RS, Brasil. Ciência Rural, v. 36, n. 2, p. 494-500, 2006.

PRIMC-HABDIJA, B.; HABDIJA, I.; RADANOVIC, I. Seasonal changes in trophic structure of periphytic ciliates in relation to discharge regime. Verhandlungen Internationale Vereiningen Limnologie, v. 26, p. 1116-1119, 1998.

RODRIGUES, A. S. L.; MALAFAIA, G.; CASTRO, P. T. A. Protocolos de avaliação rápida de rios e a inserção da sociedade no monitoramento dos recursos hídricos. Revista Ambiente \& Água, v. 3, n. 3, p. 143-155, 2008. http://dx.doi.org/10.4136/ambi-agua.68

SILVEIRA, M. P.; BUSS, D. F.; NESSIMIAN, J. L.; BAPTISTA, D. F. Spatial and temporal distribution of benthic macro invertebrates in a Southeastern Brazilian river. Brazilian Journal of Biology, n. 66, v. 2B, p. 623-632, 2006. http://dx.doi.org/10.1590/A51969842006000400006

STÖSSEL, F. Effect of the coefficients of discharge on ciliate populations of a running water contaminated by municipal wastewater. Archiv für Hydrobiologie, v. 108, p. 483-497, 1987.

SURIANO, M. T.; FONSECA-GESSNER, A. A. ROQUE, F. O.; FROEHLICH, C. G. Choice of macro invertebrate metrics to evaluate stream conditions in Atlantic Forest, Brazil. Environmental Monitoring and Assessment, v. 175, n. 1-4, p. 87-101, 2011. http://dx.doi.org/10.1007/A0661-010-1495-3

TAYLOR, W. D. A comparative study of the sessile, filter-feeding ciliates of several small $\begin{array}{llllll}\text { streams. } & \text { Hydrobiologia, } & \text { v. } & 98, & \text { p. } & 125-133,\end{array}$ http://dx.doi.org/10.1007/BF02185630

VON SPERLING M. Estudos e modelagem da qualidade da água de rios. Belo Horizonte: Editora UFMG, 2007. 588 p. 
XU, H.; MIN, G. K.; HOI, J. K.; KIM, S. J.; JUNG, J. H.; LIM, B. J. An approach to analyses of periphytic ciliate communities for monitoring water quality using a modified artificial substrate in Korean coastal waters. Journal of the Marine Biological Association of the United Kingdom, v. 89, p. 669-679, 2009. http://dx.doi.org/10.1017/S0025315409000204 